\title{
Graduate Students Academic Persistence: Academic and Social Integration Intertwined with Self-Directed Learning
}

\author{
Moi Mooi Lew ${ }^{1}$, Regena F. Nelson ${ }^{1}$, Yuqian Shen $^{1} \&$ Yung Kiet Ong ${ }^{1}$ \\ ${ }^{1}$ College of Education and Human Development, Western Michigan University, Kalamazoo, MI, USA \\ Correspondence: Moi Mooi Lew, College of Education and Human Development, Western Michigan University, \\ Kalamazoo, MI, USA. Tel: 1-269-387-3496. E-mail: moimoi.lew@wmich.edu
}

Received: November 28, 2019

Accepted: February 1, 2020

Online Published: June 5, 2020

doi:10.5539/ies.v13n7p1

URL: https://doi.org/10.5539/ies.v13n7p1

\begin{abstract}
This study aimed to explore influential personal factors that could affect graduate students' academic persistence. Data were collected with an online questionnaire and one-on-one interviews. The findings indicated that graduate students had integrated into the academic environment and established a positive relationship with advisors and program coordinators. Participants have limited social interactions with classmates. This factor decreased the importance of social integration on persistence. Data indicated that participants' self-directed learning readiness was moderately high. This study suggests that these three personal factors are intertwined in influencing graduate students' decision to persist in the academic programs.
\end{abstract}

Keywords: academic integration, academic persistence, self-directed learning, social integration

\section{Introduction}

\subsection{Introduce the Problem}

Persistence in graduate education is an issue of increasing importance. Currently there are no national databases that track the attrition rates of graduate students, and higher education institutions often lack administration procedures to track graduate students' progress on completing their programs of study (Bair \& Haworth, 2004). Research on persistence in graduate education was based on many theoretical perspectives. For example, financial aid and labor market conditions (Ampaw \& Jaeger, 2012); attribution theory (Gardner, 2009); theory of academic involvement (Austin, 2009); academic and social integration framework (Tinto, 1975, 1993); satisfaction to educational programs (Golde, 2005; Rovai, 2003); accessibility to technology and psychological support (Kemp, 2002; Quigley, 1997; Rovai, 2003). Considering persistence in graduate education is a complex phenomenon influenced by a variety of factors, in this study, the researchers were interested in exploring how academic integration, social integration (Tinto, 1975, 1993), and self-directed learning (Corno \& Kanfer, 1993) influence graduate students' academic persistence to degree completion. This study aimed to examine some personal factors that could impact the persistence of graduate students. Three research questions were formulated to guide this study:

1) How does academic integration influence graduate students' decision to persist in their studies?

2) How does social integration influence graduate students' decision to persist in their studies?

3) How does self-directed learning influence graduate students' decision to persist in their studies?

\subsection{Explore Importance of the Problem}

Academic persistence is a significant determinant of higher education institutions' effectiveness. As obtaining a graduate degree contributes to both individual and community wealth at large, it is important to identify personal factors that can reduce attrition and enhance persistence among graduate students.

\subsection{Describe Relevant Scholarship}

According to prior studies, some of the factors affecting graduate students' academic persistence include financial aid and labor market conditions (Ampaw \& Jaeger, 2012), self-motivation (Gardner, 2009), theory of academic involvement (Austin, 2009); academic and social integration (Tinto, 1993) and self-directed learning (Knowles, 1975). In this study, we explored the phenomenon using Tinto and Knowles perspectives. These three factors will be discussed in-depth in the following review. This study adopted two key concepts from Tinto's (1975)'s Student 
Integration Model. Based on this model, student's social and academic integration contribute to academic persistence. Both academic integration and social integration were examined to determine the impact on graduate students' persistence in this study. Academic integration can be explained as students' formal education in the post-secondary level which includes academic performance and interaction with faculty or staff (Pascarella \& Terenzini, 2005; Tinto, 1993). This concept was measure by grade point average (GPA) and the number of formal communications with advisors and faculty, and satisfaction with academic experience (Liu \& Liu, 2000; Tinto, 1993). Meanwhile, social integration described the informal academic life of students such as interactions with peers, faculty, and staff outside the institution (Tinto, 1975). Some research indicated that the role of academic and social integration on persistence might differ depending on the student population (Pascarella \& Terenzini, 2005). Thus, the graduate education research literature shows mixed results regarding the relationship between academic and social integration on graduate persistence.

Although Tinto (1993) had documented some identical findings between undergraduate and graduate persistence, he clarified that the differences lie in the strength of social and academic integration (Tinto, 1993). Full-time graduate students tend to have stronger academic and social integration and thus the chance for them to complete the program was found to be higher than part-time students. In the same vein, Girves and Wemmerus (1998) asserted that graduate students' persistence was influenced by student profiles, financial support, and perception towards faculty. Graduate students especially master students were concerned with the grading standards. Thus, they claimed the type of the graduate program and its associated grading standards might affect graduate students' persistence. For doctoral students, in contrast, persistence was influenced by factors such as performance on comprehensive exams, research ability, and financial support. Another factor was the perception of the academic and social relationship with a mentor.

Hagedorn (1999) carried out an exploratory study on a group of female graduate students. The logistic regression results indicated that factors such as GPA, marital status, and positive interaction among student-student and student-faculty influenced persistence among female students. Using a different perspective, Lovitts (2001) conducted a study that examined the institutional factors that influence graduate persistence. The findings indicated that students left the programs due to lack of social and academic integration within academic departments and with faculty. Lovitts (2001) also suggested that institutions can improve graduate persistence by providing departmental faculty support to students. In a more recent research, Cockrell and Shelley (2011) examined the correlation between university academic support systems and stages of the doctoral study on academic persistence. Factors such as satisfaction, academic resources and expectation in doctoral education had statistically significant correlations with persistence. Based on these findings, more attention should be given to the relationship between advisors and doctoral students.

In contrast, Al-Dossary (2008)'s findings did not support the notion that academic and social integration have any impact on persistence. He conducted a study to identify possible factors that could impact student persistence at a university in Saudi Arabia. The findings indicated that there was a positive correlation between levels of goal and institutional commitment and persistence (Al-Dossary, 2008). In other words, persister students were seen to be more engaged with a higher level of commitment than non-persister students (Al-Dossary, 2008). Hence, the literature review indicated that persistence could be supported by other factors besides academic and social integration, for example, self-directedness. Based on adult education literature, self-directed learning (SDL) was also examined for its influence on academic persistence. Adult education literature concluded that SDL is an important factor for success in graduate education (Caffarella, 1993; Garrison, 1997; Mezirow, 1985). SDL has contributed to our understanding of adult learning in formal settings and some salient characteristics of adult learners (Caffarella, 1993, p. 27).

In the literature, SDL is defined as learners taking responsibility for their own learning experience (Brockett \& Hiemstra, 1991). Based on this model, SDL is described as "a process in which individuals take the initiative to diagnose their learning needs, and evaluate learning outcomes" (Knowles, 1975, p. 10). Inevitably, (SDL) is an important attribute needed for graduate education success and professional development, yet it is seldom discussed in the research on persistence in graduate education. Kranzow and Bledsoe (2017) conducted a mixed-method research study with 91 participants to explore the impact of integrating SDL in a unit of study. Findings suggest that students understand the important role of SDL for ongoing improvement in graduate education; however, this study has not addressed how SDL could impact academic persistence.

The only study that examined the relationship between SDL and persistence is a study conducted by Mary Svedberg in 2010. Svedberg's (2010) study aimed to analyze the difference in SDL between persister students and non-persister students. Self-directed learning was not statistically significant between persisters and non-persisters. Although the participants of this study were undergraduate students, the findings laid the 
foundation for future research on graduate students. Given that many graduate programs are offered online or use a hybrid mode of instruction, more research is required to investigate whether self-directedness is corresponded to graduate persistence. In sum, the literature review shows that academic persistence and self-directed learning among graduate students have not been sufficiently studied, let alone studies that attempt to explore the impact of self-directed learning on academic persistence within this group. This study will build upon and extend previous research by contributing empirical knowledge of personal factors that could impact to graduate students' decision to persist in the programs.

\section{Method}

The study employed a mixed-methods approach to examine factors contributing to graduate students' persistence in the postsecondary programs. The quantitative data was obtained from a survey of about 100 current graduate students. One-on-one interviews were used collect in-depth qualitative data from purposefully selected participants.

\subsection{Participant (Subject) Characteristics}

The target population in this study was graduate students in doctoral and master degree programs who were enrolled in the College of Education and Human Development (CEHD). The graduate students in this college generally possess the following characteristics: are not recipients of financial aid, have dependents, attend school part-time, and are employed full-time (Giancola, Grawitch, \& Borchert, 2009; Quimby \& O'Brien, 2006). The sample selection criteria include: (1) At least three years in the graduate program, (2) Enrolled in both Fall 2016 and Spring 2017, (3) GPA above 3.0. These criteria were set based on the assumptions that a graduate student typically has to complete all the required courses within four years in the program with minimum GPA 3.0. These characteristics will assist in probing the influence of internal factors on academic persistence.

\subsection{Sampling Procedures}

In the first phase of the study, the recruitment process began by sending invitation emails to about 100 graduate students who were enrolled in the graduate program. In the second phase, ten participants were identified through purposive sampling procedures.

\subsection{Measures}

Persistence is defined as the length of time an adult attends classes and is related to drive for degree completion (Garrison, 1997; Quigley, 1997). The quantitative data was collected using a self-reported questionnaire. The survey items were adapted from studies by Pfordresher (2016) and Stockdale (2003). The academic integration (8 items) and social integration (9 items) measured the frequency of the engagement or activities in respective contexts. The Cronbach Alpha for the adapted academic integration and social integration items were .82 and .81 respectively. The self-directed learning was measured by a 24-items instrument on both the learning process and personal characteristic of self-directedness. The Cronbach Alpha were .81. The adapted survey was administered online in the Spring and Summer I 2017 semester. The questionnaire took approximately 30 minutes to complete and the participants' responses were submitted anonymously. The internal factors include academic integration, social integration (Tinto, 1975, 1993), and self-directed learning (Corno \& Kanfer, 1993). The online survey has 19 questions and the interview protocol consists of three parts. Part I: Areas related to academic integration. Part II: Factors related to social integration and Part III: Factors related to self-directed learning readiness.

\subsection{Data Analysis}

If In the first phase, descriptive statistics were used to analyze the general pattern of the quantitative data. Mean and standard deviation were computed to show the frequency for academic integration and social integration items and the degree of agreement for self-directed learning. In the second phase, Bodgan and Biklen (1998) approach was used for transcribing and analyzing the interview data for emerging themes. We first read the interview responses and then identify appropriate coding categories independently. After that, we discussed the results and agreed upon the relevant categories for the data.

\section{Results}

The project aimed to examine some influential internal factors on graduate students' academic persistence. There are three major internal factors: academic integration, social integration (Tinto, 1975, 1993), and self-directed learning (Corno \& Kanfer, 1993). Prior to conducting statistical procedures, the data set was screened for missing values and compliance to normality assumptions. We received 92 responses, after careful examination of data set by performing missing data analysis using SPSS version 20, 13 cases of incomplete responses to the questionnaire were identified. The missing data were detected because of respondent errors such as skipping an item or entering 
an invalid response. These 13 cases were excluded from further analyses, leaving an achieved sample of 79 cases. Table 1 shows the respondents' personal information that was collected through web-survey. This sample of graduate students consisted of 16 males and 63 females. In this sample, 55\% of the respondents were enrolled in the master's program and about $35 \%$ were doctoral candidates. About one-third of respondents were registered for 1-3 credit hours and another third were registered for 4-6 credit hours in the current semester. About $64 \%$ of the respondents lived off campus with less than a 30 -minute commute to the campus.

Table 1. Participants' personal information ( $\mathrm{N}=79)$

\begin{tabular}{|c|c|c|}
\hline Characteristics & Frequency $(f)$ & Percentages $(\%)$ \\
\hline \multicolumn{3}{|l|}{ Gender } \\
\hline Male & 16 & 20.3 \\
\hline Female & 63 & 79.7 \\
\hline \multicolumn{3}{|l|}{ Program } \\
\hline Master & 44 & 55.7 \\
\hline $\mathrm{PhD}$ & 28 & 35.4 \\
\hline Graduate Certificate & 4 & 5.1 \\
\hline I'm not enrolled in a program at this time & 3 & 3.8 \\
\hline \multicolumn{3}{|l|}{ Credit Hours } \\
\hline$>9$ credits & 5 & 6.3 \\
\hline $7-9$ credits & 6 & 7.6 \\
\hline $4-6$ credits & 26 & 33 \\
\hline $1-3$ credits & 27 & 34.2 \\
\hline I'm not currently taking any credits this semester & 15 & 19.0 \\
\hline \multicolumn{3}{|l|}{ Time Commute to Campus (minutes) } \\
\hline $5-15$ & 30 & 38.0 \\
\hline $15-30$ & 21 & 26.6 \\
\hline $30-45$ & 9 & 11.4 \\
\hline $45-60$ & 8 & 10.1 \\
\hline$>60$ & 11 & 13.9 \\
\hline \multicolumn{3}{|l|}{ Cumulative GPA } \\
\hline 4.00 & 17 & 21.5 \\
\hline $3.81-3.99$ & 24 & 30.4 \\
\hline $3.61-3.80$ & 23 & 29.1 \\
\hline $3.41-3.60$ & 7 & 8.86 \\
\hline $3.21-3.40$ & 3 & 3.79 \\
\hline $3.11-3.20$ & 1 & 1.26 \\
\hline $3.01-3.10$ & 1 & 1.26 \\
\hline$<3.00$ & 1 & 1.26 \\
\hline Missing Value & 2 & 2.53 \\
\hline
\end{tabular}

Question 1: how does academic integration influence graduate student decision to persist in their studies?

Table 2. Academic integration ( $\mathrm{N}=79)$

\begin{tabular}{lcc}
\hline Statement & Mean & Standard Deviation \\
\hline I have spoken to faculty members about course-related information & 4.63 & 1.59 \\
I have discussed personal concerns or problems with a faculty member & 2.78 & 1.72 \\
I have discussed career plans with a faculty member & 3.91 & 1.78 \\
I have met informally with a faculty member on a project or paper & 3.01 & 1.86 \\
My professors are available to answer questions outside of class & 4.87 & 1.68 \\
My professors encourage me to interact in classroom activities & 5.41 & 1.61 \\
My professors take an interest in my well-being and academic success & 4.87 & 1.87 \\
I feel academically challenged by my professors & 5.39 & 1.51 \\
\hline
\end{tabular}

Academic integration is defined as how well graduate students navigate in their daily academic life in the higher 
institution and is measured by cumulative grade point average (GPA). Based on the cumulative GPA, it indicated that the respondents were academically integrated with the graduate program as about $80 \%$ of the respondents obtained GPA above 3.6 (mean $=3.80, \mathrm{SD}=0.23$ ). This finding was supported by the interview data. All ten of the interview participants claimed that they were motivated to persist in the program due to their high GPA scores. Academic integration was also explored through the connection they had built with their professors and support provided by the faculty members. Table 2 shows how frequent the respondents were connected with their faculty members for academic purposes based on a scale 1 (never) to 7 (frequently).

The data indicate that the respondents felt that they are frequently academically challenged by their professors (Mean $=5.39, \mathrm{SD}=1.51)$ and their professors were frequently encouraged them to interact in classroom academic activities (Mean $=5.41, \mathrm{SD}=1.61$ ). In addition, respondents frequently spoke to faculty members about course-related information (Mean $=4.63, \mathrm{SD}=1.59$ ). Professors were frequently available to answer questions outside of class (Mean $=4.87, \mathrm{SD}=1.69$ ), and took an interest in the well-being and success (Mean $=4.87, \mathrm{SD}=$ 1.87). These findings are supported by interview data for reasons why they persist in the program. Overall, the qualitative findings substantiate the quantitative findings in emphasizing the importance of student advising. The interview participants were named P1 to P10 when direct quotations were used to supplement the results. The majority of graduate students have established a positive relationship with advisors and program coordinators. The faculty and staff are always accessible and helpful. Nevertheless, they have few in-person interactions with faculty outside of class.

Academic resources and support provided by the college. Participants were aware of the outside-of-class activities but seldom join those activities. The resources that they use most are library resources such as online journals, e-book, e-reserve platform etc. Even though they knew that the college has a series of writing workshops and has a writing coach, they have not used these academic resources. Academic problems while taking classes. Students who were taking online classes had fewer academic problems as the online classes were very structured and had clear expectations. The other problems related to time management between academic and daily life commitment. In addition, some participants commented that there was inconsistency in terms of faculty's quality in conducting online courses. Some commented that the course had no syllabus and the inconsistency among syllabi between faculty. The program has some course scheduling issues. There are a limited number of courses offered for each semester, especially in summer. The issue of applicability of the assignments for their future work was also noted. Some suggested that faculty teaching online classes should do more to monitor students' progress on their program plans.

Some respondents commented that many advisors were rather slow in responding to student's emails, and were passive in communicating with their advisees. In particular, they hoped that advisors could act fast in providing information related to credit audits and graduation. Some respondents stated that many faculty members seemed unaware of the fact that students mostly were non-traditional graduate students when designing course assignments. They hoped that faculty could provide more input on course content, give feedback on assignments, be more consistent in terms of program expectations, and be accessible outside of business hours. The participants suggested extending the service hour of the libraries, hiring more staff to better address student needs and assigning more study rooms for graduate students. They also requested more research and travel funding to support their travel to conferences. For those residing outside of main campus, they suggested that the college could offer more resources beyond the main campus. For example, they suggested providing the graduate students a temporary license for required course software (SPSS). It would be more convenient if they had the software on their computers. The students also suggested that the college or department organize program orientation for new graduate students. This would allow students to know the program of study, the course sequence, program structures, E-learning platform navigation, and anticipated graduation dates. The respondents hoped that there would be more course offerings to accommodate students' needs and schedules. Some respondents suggested that only good instructors should be assigned to teach online courses. For a particular program, respondents stated that several professors had been discouraging, violated FERPA, and expressed sexist and heterosexist attitudes, which create an unsafe academic environment. Many respondents were concerned about employment upon graduation and professional development resources. They hope that the college or department will discuss the availability of post-doctoral study opportunities, upcoming career paths, internship opportunities, and job postings for students who expected to graduate soon. In terms of academic scholarly involvement, the survey data shows that only $17 \%$ of the respondents were interested in becoming a member of an academic organization and less than $33 \%$ of the respondents are interested in participating in academic research projects or conferences. This is congruent with the interview data that they were aware of the out-of-class activities, but they seldom join those activities. The resources that they use most were the library resources such as online journals, e-book, e-reserve platform etc. 
Even though they knew that the college has a series of writing workshops and has a writing coach, they have not used these academic resources.

Question 2: how does social integration influence graduate student decision to persist in their studies?

Table 3. Social integration $(\mathrm{N}=79)$

\begin{tabular}{|c|c|c|}
\hline Statement & Mean & Standard Deviation \\
\hline I have made friends with students in my classes & 4.57 & 1.79 \\
\hline I have made friends with other students on campus & 3.08 & 1.99 \\
\hline I have met with my classmates to work on class assignments together & 4.34 & 2.00 \\
\hline I have made friends with students whose age, race, interests or personal values are different than mine. & 4.90 & 1.70 \\
\hline I have met with my classmates for social interactions. & 3.34 & 2.13 \\
\hline I feel a sense of belonging at this college. & 4.23 & 1.87 \\
\hline I read and respond to e-mails from my instructors. & 6.06 & 1.42 \\
\hline I participated in one or more activities my faculty invited me to. & 3.23 & 1.95 \\
\hline I spend time on campus (outside of class) involved in co-curricular or co-curricular activities. & 2.29 & 1.69 \\
\hline
\end{tabular}

Table 4. Times spent on campus activities or events

\begin{tabular}{lc}
\hline Categories & Frequency \& Percentage \\
\hline More than 8 hours per week & $1(1.27 \%)$ \\
$2-5$ hours per week & $3(3.79 \%)$ \\
$1-2$ hours per week & $15(19.0 \%)$ \\
Less than one hour per week & $60(75.95 \%)$ \\
\hline
\end{tabular}

Social integration is defined as students' interpersonal relationships with peers, faculty, and staff to create a sense of community and campus life engagement (Tinto, 1975). Social integration is measured by the number of positive interactions with peers and faculty and extracurricular activities (Tinto, 1975). Table 3 shows how frequent respondents were connected with their classmates and instructors based on a scale 1 (never) to 7 (frequently). The data indicate that the respondents felt that they frequently read and respond to e-mails from their instructors (Mean $=6.06, S D=1.42)$; they have made friends with classmates in their classes $($ Mean $=4.57, S D=1.79)$ and have made friends with classmates whose age, race, interests or personal values are different from them $($ Mean $=4.90$, $S D=1.70)$. The respondents felt that they "never" spend time on campus outside of class by participating in co-curricular activities $($ Mean $=2.29, S D=1.69)$. About $76 \%$ of the respondents reported that they spent less than one hour per week attending campus activities or events (refer to Table 4). The findings are supported by interview data that the majority of the respondents have limited social interaction with classmates outside of the class. Overall, about $62 \%$ of the respondents were satisfied with the social aspects of their educational experience.

Some participants felt that social integration is important and it has helped them persist in the program. The importance of social integration is bound by the program major and program level. Participants from Counseling Education major background need social support groups to share the problems they encounter during their daily counseling services. Likewise, doctoral respondents felt that social integration inspires them to persist in the program by sharing research information and perspectives. Not surprising to hear from participants who are in online programs that social integration is less important to them as they hardly connect with anyone in the same course in any social environment. Some participants have good social interaction and have the opportunity to experience other people's insight. However, the majority of the respondents have limited social interaction with classmates outside of the class. Below are some verbatim expressions of the interview participants.

When asked about the problems they faced while social interactions with faculty, staff and classmates, the majority of the respondents do not seem to have a problem because they have limited social interaction with faculty besides email. The issue is time and location. They interacted more with faculty and staff compared to classmates. In terms of a sense of belonging to the college, only two of the interview participants have a sense of belonging to the college as they were in the college as undergraduate students. The majority of the graduate students has no or slight sense of belonging due to the short time frame for their programs and the nature of the courses. For example, typically, they take about 2-3 years to complete a master's program and they usually attend classes one or twice a week. Some participants suggested creating a social network or events for working parents so that they use this opportunity to meet fellow course mates. They also suggested that the professors assign online office hours and 
creating more face time for advising. The college could create more opportunities to connect with faculty, staff and classmates in the Extended University Program (EUP) Centers to provide support to graduate students to persist in their graduate education.

Question 3: how does self-directed learning influence graduate student decision to persist in their studies?

Table 5. Self-directed learning $(\mathrm{N}=79)$

\begin{tabular}{|c|c|c|c|}
\hline $\begin{array}{l}\text { Item } \\
\text { No. }\end{array}$ & Statements & Mean & $\begin{array}{l}\text { Standard } \\
\text { Deviation }\end{array}$ \\
\hline 1 & I never have a problem carrying out my study plans. & 4.71 & 1.90 \\
\hline 2 & I frequently do extra work in a course just because I am interested in the answers. & 4.65 & 1.66 \\
\hline 3 & I always view problems I encounter in my learning as the personal challenges I can overcome. & 5.43 & 1.32 \\
\hline 4 & I consistently motivate myself to do well in any course I take. & 6.15 & 1.06 \\
\hline 5 & $\begin{array}{l}\text { I usually do better in course when the instructor tells me exactly what I need to learn rather than when I } \\
\text { chose my own topics for learning. }\end{array}$ & 4.61 & 1.60 \\
\hline 6 & $\begin{array}{l}\text { If I am not doing as well as I would like in a course I always independently make the changes necessary } \\
\text { for improvement. }\end{array}$ & 5.58 & 1.52 \\
\hline 7 & I always feel in control of the learning process. & 4.86 & 1.49 \\
\hline 8 & I usually struggle in classes if the professor allows me to set my own timetable for work completion. & 3.09 & 1.87 \\
\hline 9 & $\begin{array}{l}\text { I would rather take the initiative to learn new things in a course rather than wait for the instructor to foster } \\
\text { new learning. }\end{array}$ & 4.04 & 1.43 \\
\hline 10 & I always depend on the instructor to make sense of things I don't understand. & 3.14 & 1.52 \\
\hline 11 & I often collect additional information about interesting topics even after the course has ended. & 5.06 & 1.46 \\
\hline 12 & If there is something I don't understand in a class, I always try to find a way to learn it on my own. & 5.38 & 1.22 \\
\hline 13 & $\begin{array}{l}\text { Without the instructor's help, I always have a problem knowing what changes I need to make to improve } \\
\text { my learning. }\end{array}$ & 3.06 & 1.47 \\
\hline 14 & I usually find a way to relate my research projects for a course to my own interests. & 5.78 & 1.02 \\
\hline 15 & I always effectively take responsibility for my own learning. & 6.11 & 1.01 \\
\hline 16 & I am very successful at prioritizing my own learning. & 5.73 & 1.13 \\
\hline 17 & The instructor is always in control of what I learn about a topic. & 3.01 & 1.39 \\
\hline 18 & I have taken elective courses simply because they were personally useful. & 4.95 & 1.97 \\
\hline 19 & I often use materials I've found on my own to help me in a course. & 5.33 & 1.43 \\
\hline 20 & I always effectively organize my study time. & 4.82 & 1.66 \\
\hline 21 & I always assume personal responsibility for my learning. & 6.18 & 1.00 \\
\hline 22 & I often have a problem motivating myself to learn. & 2.92 & 1.62 \\
\hline 23 & I always rely on the instructor to tell me what I need to do on a course to succeed. & 3.25 & 1.61 \\
\hline 24 & Even after a course is over, I often continue to spend time learning about the topic. & 4.96 & 1.40 \\
\hline
\end{tabular}

The self-directed learning factor was also examined for its influence on academic persistence. Self-directed learning described how individuals take the initiative to evaluate their learning needs and develop their learning goals (Brockett \& Hiemstra, 1991). Table 5 shows the respondents' degree of agreement to items reflected on the self-directed learning readiness based on a scale of 1 (strongly disagree) to 7 (strongly agree). The respondents gave a rating of "moderately agree" to the following items: "I always view problems I encounter in my learning as the personal challenges I can overcome." (Mean $=5.43, S D=1.32)$; "I consistently motivate myself to do well in any course I take" (Mean $=6.15, S D=1.06)$; "If I am not doing as well as I would like in a course I always independently make the changes necessary for improvement." (Mean $=5.58, S D=1.52$ ); "I usually find a way to relate my research projects for a course to my own interests. " (Mean $=5.78, S D=1.02)$; "I always effectively take responsibility for my own learning.' (Mean $=6.11, S D=1.01$ ); "I am very successful at prioritizing my own learning." (Mean $=5.73, S D=1.13$ ) and "I always assume personal responsibility for my learning." (Mean = 6.18, $S D=1.00)$.

Based on the interview data, this group of graduate students has a high degree of self-directed readiness. They knew how to navigate and access resources. They have a passion to learn and usually allocate self-study time for assignments and reading. All the participants agreed that self-directed learning is important for persisting in the program as most of the courses are online courses. The doctoral participants stated that they needed self-directed learning attributes to keep them moving forward in the dissertation writing stage. The participants shared some 
strategies that they use to study such as reading through the syllabus to understand course expectations, looking for additional resources if they feel the readings are lacking important content, communicating with instructors, setting up a time to access information etc. Some use a calendar, to do lists, and flashcards to keep themselves organized. When asked about the problems faced while self-monitoring their studies, they claimed that for non-traditional graduate students, the time factor is always the main issue. Some of them felt that they have difficulties in balancing time for work, study and family responsibilities. Sometimes they just could not follow the schedules to complete the assignments. Some participants reflected that communicating with husband/wife is an important factor in improving self-directed learning. Their partner's motivation is the key factor for their success. Some felt that planning is important too. They were careful not take too many courses in one semester. For doctoral participants, they usually take time off for dissertation writing.

In sum, about $78 \%$ of the respondents were satisfied with their academic experience at the College of Education and Human Development. There is inconsistency in terms of faculty's quality in conducting online courses. Some commented that some courses did not have a syllabus and there was inconsistency among the faculty's syllabi. The program has a limitation in terms of course scheduling. There were limited course offerings each semester especially in the summer. Some respondents were not aware of the program structure. The issue of applicability of the assignments for their future work was also brought up. Some participants suggested that faculty should reach out to their students to make sure they are following their program plan. Overall, only $62 \%$ of the respondents were satisfied with their social interaction experience at the College of Education and Human Development. There is inconsistency in terms of the respondents' ratings of the importance of social integration for persisting in the program. This aspect is less important compared to academic integration. In terms of a sense of belonging to the college, the majority of the graduate students have no or slight sense of belongs due to a short time frame of their programs and the nature of the courses. Regarding self-directed learning, this group of graduate students has a high degree of self-directed learning readiness. They knew how to navigate and access resources. They have a passion to learn and usually allocate self-study time for assignments and reading. They agreed that they consistently motivate themselves to do well in all courses and always make changes for improvement. They have always taken responsibility for and prioritized their learning.

\section{Discussion}

Findings of this study were in accordance with some previous studies regarding persistence among graduate students in CEHD. First, based on $80 \%$ of the survey respondents reported that they obtained high GPA (mean = $3.80, \mathrm{SD}=0.23$ ) this indicated that they were academically integrated with the graduate program. All the ten interview participants claimed that they were motivated to persist in the program due to their high GPA scores. The findings are in accordance with Girves and Wemmerus (1998) and Hagedorn (1999) even though the time lapse between both studies and this study is more than 15 years. Both Girves and Wemmerus (1998) and Hagedorn (1999) claimed that GPA is an indicator of persistence. Second, the findings about the important role of academic and social integration are also in agreement with many other studies (Cockrell \& Shelley, 2011; Hagedorn, 1999; Liu \& Liu, 2000; Lovitts, 2001; Pascarella \& Terenzini, 2005; Tinto, 1993; Xu, 2015). In this study, academic integration was explored through the connection they build with their professors and support provided by the faculty members. The findings indicated that the professors frequently encourage them to interact in classroom activities and they were frequently challenged academically by professors. The majority of graduate students have established a positive relationship with their advisors and program coordinator. About $78 \%$ of the participants were satisfied with their academic experience in the college's academic environment. Similarly, both Hagedorn (1999) and Xu's (2015) studies claimed that keeping a positive student-student and student-faculty interactions will lead to persistence. Lovitts' (2001) study stated that those who are engaged in strong professional relationships with a faculty member would persist in their graduate programs. The study findings of Lovitts (2001) asserted that institutions can encourage persistence with the support of departmental faculty. Additionally, the findings were supported by Pascarella and Terenzini (2005). They suggested that students' decisions to persist in the program were affected by the quality of academic advising they received. This is evidenced that many students who dropped out had a poor academic advising experience. Indeed, academic advising is an important process for faculty and staff in helping students making decisions and executing actions to achieve their educational and career goals $(\mathrm{Xu}, 2015)$.

Third, overall, only $62 \%$ of the respondents were satisfied with their social interaction experience at the College of Education and Human Development. There is inconsistency in terms of the importance of social integration for persisting in the program between online learners and face-to-face program students. For online program students, they felt that this aspect is less important compared to academic integration. In terms of a sense of belonging to the college, the majority of the graduate students have little or no sense of belonging due to the short time frame for 
their programs and the nature of the courses. It seems that graduate students may not consider social integration factors when planning to persist or not persist in graduate education. The findings are in accordance with Al-Dossary's (2008) findings that academic integration and social integration are not significant factors in the difference between persister and non-persister students. Nonetheless, the findings were contrary to most of the past research findings (Cockrell \& Shelley, 2011; Hagedorn, 1999; Lovitts, 2001). For example, Cockrell and Shelley's (2011) study indicated that formal academic support systems and student satisfaction with the advisor relationship are important factors for academic persistence. Additionally, past research indicates colleges that provide meaningful social opportunities will help reduce the difficulties inherent in the graduate education (Cockrell and Shelley, 2011; Hagedorn, 1999; Lovitts, 2001; Tinto, 1993).

Lastly, the literature review indicated that persistence in graduate education could be supported by self-directedness. Self-directed learning described how individuals take the initiative to understand their learning needs (Knowles, 1975). The participants shared some study strategies. All the participants agreed that self-directed learning is important for persisting in the program as most of the courses use an online platform. The doctoral participants emphasized that they really need self-directed learning attributes to keep them moving forward in the dissertation stage. The findings indicated the self-directedness is crucial for program persistence and are congruent with research findings in Kranzow and Bledsoe (2017). In Kranzow and Bledsoe's (2017) study, participants understood the centrality of SDL for ongoing improvement in graduate education. In contrast, the findings are incongruent with findings in Svedberg's study. Svedberg's (2010) study found that self-directed learning was not statistically significantly different among persisters and non-persisters. Thus, more research should be carried out to ascertain the relationship between SDL and graduate persistence.

There are several aspects of this study that limit our findings and raise questions to be addressed in future research. First, the findings have limited generalizability due to bias in the selection of participants. The respondents for the survey were in a convenience sample of students enrolled in the graduate programs in the college. Participants who volunteered to participate in the interviews may not be representative of graduate students who live off-campus. Perhaps those graduate students who agreed to participate in the study have fewer academic persistence issues than those who decline to participate. Second, the number of the respondents for the survey was small and this limits generalizability of the findings in this study too. Third, the study did not used inferential statistics to analyze the quantitative data. Therefore, the difference between groups might have happened by chance. The limitations of this study point towards aspects to be addressed in the future. Future research is recommended to use a larger sample size for the survey and take steps to reduce the selection bias for the sample. Inferential statistics should be used to justify the claims for any observed differences between groups for factors that impact academic persistence. Additional research is needed to investigate the impact of institutional factors such as scholarships and external support systems on graduate academic persistence to expand our understanding in this field of study.

\section{Conclusion}

To conclude, the three investigating factors, academic integration, social integration and self-directed learning are intertwined in influencing graduate students' decision to persist in the programs. Academic persistency needs self-directed learning attitudes coupled with satisfying academic and social experiences in college. Nonetheless, a higher percentage of graduate students are satisfied with their academic integration experience as compared to their social integration experience. Graduate students are more concern with the quality of the programs, the professionalism of the faculty members, and the academic services provided by the college than fostering social connections within the university community. The findings asserted that institutions can improve persistence by providing academically challenging programs with departmental faculty social support. Student satisfaction with their advisor relationship was an important factor for academic persistence. Due to incongruent results with past research in relation to self-directedness, more research should be carried out to ascertain the relationship between SDL and persistence. As obtaining a graduate degree contributes to both individual and community wealth at large, this study suggests that institutions and policymakers focus on strengthening graduate student personal factors as a way to reduce attrition and enhance persistence. The study presented data on the crucial role of integrating the graduate student population into the academic and social systems of the college to enhance persistence.

\section{References}

Al-Dossary, S. A. (2008). A study of the factors affecting student retention at King Saud University, Saudi Arabia: Structural equation modelling and qualitative methods (Doctoral dissertation, University of Stirling, Scotland, United Kingdom). $\quad$ Retrieved $\quad$ from https://pdfs.semanticscholar.org/9fb2/f98ab4361d5b69197c2e85a4fae747b44640.pdf

Ampaw, F. D., \& Jaeger, A. J. (2012). Completing the Three Stages of Doctoral Education: An Event History 
Analysis. Research on Higher Education, 53, 640-660. https://doi.org/10.1007/s11162-011-9250-3

Austin, A. E. (2009). Cognitive apprenticeship theory and its implications for doctoral education: A case example from a doctoral program in higher and adult education. International Journal for Academic Development, 14(3), 173-183. https://doi.org/10.1080/13601440903106494

Bogdan, R. C., \& Biklen, S. K. (1998). Qualitative research in education: An introduction to theory and Methods (3rd ed.). Boston, MA: Allyn \& Bacon.

Brockett, R. G., \& Hiemstra, R. (1991). Self-direction in adult learning: Perspectives on theory, research, and practice. New York: Routledge \& Kegan Paul.

Caffarella, R. S. (1993). Self-directed learning. New Directions for Teaching and Learning, 57, 25-35. https://doi.org/10.1002/ace.36719935705

Cockrell, C. N., \& Shelley, K. (2011). The relationship between academic support systems and intended persistence in doctoral education. Journal College Student Retention, 12(4), 469-484. https://doi.org/10.2190/CS.12.4.e

Corno, L., \& Kanfer, R. (1993). The role of volition in learning and performance. Review of Research in Education, 19, 301-341. https://doi.org/10.2307/1167345

Gardner, S. K. (2009). Student and faculty attributions of attrition in high and low-completing doctoral programs in the United States. Higher Education, 58(1), 97-112. https://doi.org/10.1007/s10734-008-9184-7

Garrison, D. R. (1997). Self-directed learning: Toward a comprehensive model. Adult Education Quarterly, 48(1), 18-33. https://doi.org/10.1177/074171369704800103

Giancola, J., Grawitch, M., \& Borchert, D. (2009). Dealing with the stress of college: A model for adult students. Adult Education Quarterly, 59(3), 246-263. https://doi.org/10.1177/0741713609331479

Girves, J. E., \& Wemmerus, V. (1988). Developing models of graduate student degree progress. Journal of Higher Education, 59, 163-189. https://doi.org/10.2307/1981691

Golde, C. M. (2005). The role of the department and disciplines in doctoral student attrition: Lessons from four departments. The Journal of Higher Education, 76(6), 669-700. https://doi.org/10.1353/jhe.2005.0039

Hagedorn, L. S. (1999). Factors related to the retention of female graduate students over 30. Journal of College Student Retention, 1(2), 99-114. https://doi.org/10.2190/LKWC-EJUB-V5KM-BRNQ

Kemp, W. C. (2002). Persistence of adult learners in distance education. American Journal of Distance Education, 16(2), 65-81. https://doi.org/10.1207/S15389286AJDE1602_2

Knowles, M. (1975). Self-directed learning: A guide for learners and teachers. New York: Association Press.

Kranzow, J., \& Bledsoe, T. S. (2017). Self-directed learning: Pedagogical influences on graduate student perspectives. International Journal of Adult Vocational Education and Technology, 8(3), 44-54. https://doi.org/10.4018/IJAVET.2017070104

Liu, R., \& Liu, E. (2000). Institutional integration: An analysis of Tinto's theory. Cincinnati, OH: Annual Forum of the Association for Institutional Research.

Lovitts, B. E. (2001). Leaving the ivory tower. Lanham: MD: Rowman and Littlefield.

Mezirow, J. (1985). A critical theory of self-directed learning. New Directions for Teaching and Learning, 25, 17-29. https://doi.org/10.1002/ace.36719852504

Pascarella, E., \& Terenzini, P. (2005). How college affects students, Volume 2: A third decade of research. San Francisco: Jossey-Bass.

Pfordresher, H. M. (2016). Persistence factors for nontraditional undergraduate students at a Northeast Catholic College (Master's thesis).

Quigley, B. (1997). Rethinking literacy education: The critical need for practice-based change. San Francisco: Jossey-Bass.

Quimby, J. L., \& O’Brien, K. M. (2006). Predictors of well-being among nontraditional female students with children. Journal of Counseling \& Development, 84, 451-460.

Rovai, A. P. (2003). In search of higher persistence rates in distance education online programs. The Internet and Higher Education, 6(1), 1-16. https://doi.org/10.1016/S1096-7516(02)00158-6 
Stockdale, S. L. (2003). Development of an instrument to measure self-directedness (Doctoral dissertation). Retrieved from http://trace.tennessee.edu/utk_graddiss/1619

Svedberg, M. K. (2010). Self-directed learning and persistence in online asynchronous undergraduate programs (Doctoral dissertation, Virginia Polytechnic Institute and State University). Retrieved from http://hdl.handle.net/10919/26666

Tinto, V. (1975). Dropout from higher education: A theoretical synthesis of recent research. Review of Educational Research, 45(1), 89-125. https://doi.org/10.3102/00346543045001089

Tinto, V. (1993). Leaving college: Rethinking the causes and cures of student attrition. Chicago: University of Chicago Press. https://doi.org/10.7208/chicago/9780226922461.001.0001

$\mathrm{Xu}, \mathrm{Y} . \mathrm{H}$. (2015). Advance to and persistence in graduate school: Identifying the influential factors and major-based differences. Journal of College Student Retention, 16(3), 391-417. https://doi.org/10.2190/CS.16.3.e

\section{Copyrights}

Copyright for this article is retained by the author(s), with first publication rights granted to the journal.

This is an open-access article distributed under the terms and conditions of the Creative Commons Attribution license (http://creativecommons.org/licenses/by/4.0/). 